\title{
Jy het 'n mooi vrou
}

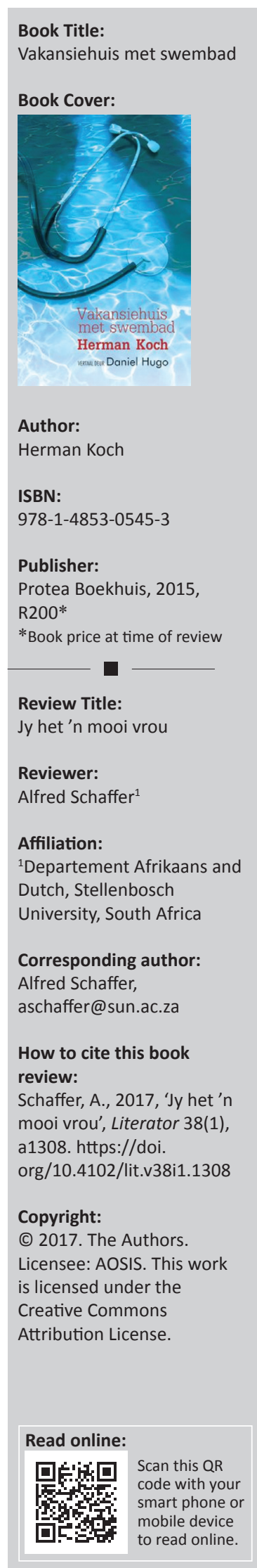

In 2011 verskyn die roman Zomerhuis met zwembad van die Nederlandse skrywer Herman Koch. Koch was aanvanklik veral bekend as een van die vervaardigers van absurde televisieprogramme onder die naam Jiskefet. Reeds in 1989 verskyn sy debuutroman egter: Red ons, Maria Montanelli. Tog is dit eers met Het diner (2009) dat Koch bekend word as 'n suksesvolle skrywer. Het diner is gepubliseer in 40 lande en was weke lank boaan die topverkoperlys van The New York Times, met wêreldwyd meer as 2.5 miljoen verkope. Met Het diner, wat in 2013 met die titel Die aandete ook by Protea Boekhuis verskyn in die vertaling van Daniel Hugo, lyk dit of Koch 'n effektiewe verhaalformule beet het, een wat steun op aansprekende morele dilemmas en 'n uitstekende aanvoeling vir'n goeie plot. 'n Herkenbare problematiek wat saamhang met die welgestelde WesEuropese middelklas word gekombineer met absurde, makabere humor in toeganklike taal.

Vakansiehuis met swembad se sentrale tema kom ooreen met dié van Die aandete: In watter mate mag of kan jy jou kinders beskerm teen die wrede ingrepe van die wêreld daarbuite? En hóéveel van die wêreld daarbuite skuil feitlik binne-in jouself?

Mark Schlosser is die tipiese hoofpersoon van 'n Koch-verhaal: hierdie huisdokter met 'n afkeer van mense is suksesvol én 'n buitestander, en word gedryf deur aansteeklike sarkasme en sinisme. Die verhaal speel grotendeels af in en rondom 'n vakansiehuis (waarskynlik in Frankryk), maar die karakters is tiperend van die kulturele elite van Amsterdam, meer spesifiek Amsterdam-Zuid. Hier bly die kunstenaars, die mense met geld en aansien, dié wat almal liefs begrawe wil word in die begraafplaas wat vir Nederlandse lesers herkenbaar is as Begraafplaats Zorgvlied aan die rivier De Amstel, in die roman bloot 'die begraafplaas in die elmboog van die rivier'. In hierdie biotoop, wat voorheen al voortreflik ontmasker is deur Arnon Grunberg in sy roman Tirza (2006), is Schlosser se pasiënte veral skilders, akteurs en skrywers. Dit bied die moontlikheid om die Nederlandse kulturele wêreld met sarkasme tegemoet te tree (bl. 40):

Ek vertel hulle wat hulle wil hoor. Ek noem 'n naam. Pablo Picasso, sê ek. Pablo Picasso was ook nie afkerig van drank nie. Die noem van dié naam dien 'n tweeledige doel. Deur my pasiënte in dieselfde asem te noem met ' $n$ wêreldberoemde kunstenaar, voel hulle self ook 'n rukkie lank hulle is Pablo Picasso. Ek sou dit anders kon formuleer. U is 'n baie groter suiplap as Pablo Picasso, sou ek kon sê, maar u besit nie 'n tiende van sy talent nie. Goed beskou is dit 'n verspilling. Verspilling van alkohol, vir alle duidelikheid.

Mark Schlosser is getroud met 'n pragtige vrou, Caroline, en een van sy beroemde pasiënte is die akteur Ralph Meier, 'n macho man wat elke vrou wil verower. Mark en Caroline word na die openingsaand van Richard II genooi waarin Meier die hoofrol speel, en na afloop vind 'n ontmoeting plaas tussen Mark en Caroline, en Ralph en sý eggenote, Judith. Dit is direk duidelik dat Ralph Meier vir Caroline begeer (bl. 36):

'n Mens sien dit van tyd tot tyd by roofvoëls in natuurfilms. Roofvoëls wat êrens onder hulle, hoog uit die lug of van 'n boomtak, 'n muis of 'n ander smaaklike happie ontdek het. So bekyk Ralph Meier my vrou se liggaam: as iets eetbaars wat sy mond laat water.

Ralph en sy vrou Judith raak teen wil en dank bevriend met die Meiers. 'Toevallig' beland die Schlossers met hulle twee jong en beeldskone dogters, Julia en Lisa, in die vakansiehuis van Ralph en Judith en húlle twee mooi seuns, Alex en Thomas. Dan is daar die enigmatiese filmregisseur Stanley (deels gebaseer op die Nederlandse filmregisseur Paul Verhoeven) wat met sy vriendin Emanuelle van so veertig jaar jonger ook in die vakansiehuis loseer.

Hierdie roman is so onderhoudend soos 'n spannende Amerikaanse HBO-reeks, met boonop 'n onbetroubare vertelperspektief. Terloops bevat hierdie teatrale, fragmentariese monoloog vol terugflitse kritiek op allerhande maatskaplike sake soos ontrou, kindermolestering, waglyste in die gesondheidsorg, glanslewens, vrouemishandeling, pedofilie en die gesin as die bom onder die samelewing. Te ernstig raak dit nie; daar is byvoorbeeld nie sprake van 'n deurdringende, krities filosofiese visie op die Westerse mens nie. Dit is ook nie dié roman se ambisie nie. 
Vakansiehuis met swembad, wat weereens die groot vertaaltalent van Daniel Hugo uitwys, lees soos 'n literêre riller; in die hoofrol 'n man wat nota bene sy verhaal begin deur te sê dat hy voor die Mediese Raad moet verskyn op 'n aanklag moord op Ralph Meier. Sowel lesers wat hou van 'n meesleurende boek as leeskringe sal dié boek met groot plesier lees. 